\title{
Pengaruh Multiple Intelligences Terhadap Prestasi Belajar Mahasiswa:Studi pada Mahasiswa Jurusan Sejarah IKIP Budi Utomo Malang
}

\author{
Septa Rahadian \\ Program Studi Pendidikan Sejarah dan Sosiologi IKIP Budi Utomo Malang \\ Jalan Citandui 46 Malang \\ septa.rahadian@gmail.com \\ Arif Wahyu Hidayat \\ Program Studi Pendidikan Sejarah dan Sosiologi IKIP Budi Utomo Malang \\ Jalan Citandui 46 Malang \\ wahyu.arif32@gmail.com
}

\begin{abstract}
This research aims to determine the effect of Multiple Intelligences toward learning achievement in college history and sociology department IKIP Budi Utomo Malang. The method used in this study is the experimental method kind of explanatory research. The data obtained from the analysis of Multiple Intelligences questionnaire and analyzed using multiple linear regression. From the results of this research showed no significant difference between linguistic intelligence, logic and intra personal on learning achievement college student history and sociology department IKIP Budi Utomo. From the analysis of the data obtained coefficient R2 of 0.079 indicates variable linguistic intelligence, logic and intrapersonal have an influence on the learning achievement of $7.9 \%$ while the remaining $92.1 \%$ is influenced by other variables not examined. Suggestions from this research are expected to party institution is willing to conduct training on making and writing papers or scientific work so that students are able to make posts or tasks properly. were all students majoring history and sociology department IKIP Budi Utomo Malang.
\end{abstract}

Keywords: Multiple Intelligences, linguistic, logical, interpersonal, academic achievement

Multiple Intelligences yang dalam bahasa Indonesia diterjemahkan sebagai kecerdasan majemuk atau kecerdasan ganda merupakan salah satu teori kecerdasan yang memperoleh banyak pengakuan akhir-akhir ini Kecerdasan menurut Gardner diartikan sebagai suatu kemampuan, dengan proses kelengkapannya, yang sanggup menangani kandungan masalah yang spesifik di dunia. Meskipun demikian, tidak berarti bahwa orang yang memiliki jenis kecerdasan tertentu, kecerdasan musikal misalnya, akan menunjukkan kemampuan tersebut dalam setiap aspek hidupnya.

Kehadiran ciri-ciri pada individu menentukan kadar profil kecerdasannya. Dalam kehidupan nyata, kecerdasankecerdasan itu hadir dan muncul bersamasama atau berurutan dalam suatu atau lebih aktivitas. Dalam kasus khusus, ditengarai adanya individu savant, yakni orang yang memiliki tingkat kecerdasan yang sangat tinggi pada satu jenis kecerdasan, namun rendah dalam kecerdasan yang lain. Dalam dunia pendidikan, teori multiple intelligences 
mulai diterima karena dianggap lebih melayani semua kecerdasan yang dimiliki anak. Konsep MI menjadikan pendidik lebih arif melihat perbedaan, dan menjadikan anak merasa lebih diterima dan dilayani. Konsep ini "menghapus" mitos anak cerdas dan tidak cerdas, karena menurut konsep ini, semua anak hakikatnya cerdas. Hanya saja konsep cerdas itu perlu diredefinisi dengan landasan baru.

Menurut Kamus Umum Bahasa Indonesia, pengertian prestasi adalah hasil yang telah dicapai (dari yang telah diakukan, dikerjakan, dan sebagainya) (1991: 787). Sedangkan menurut Saiful Bahri Djamarah (1994: 20-21) dalam bukunya Prestasi Belajar dan Kompetensi Guru, bahwa prestasi adalah apa yang telah dapat diciptakan, hasil pekerjaan, hasil yang menyenangkan hati yang diperoleh dengan jalan keuletan kerja. Dalam buku yang sama Nasrun harahap, berpendapat bahwa prestasi adalah penilaian pendidikan tentang perkembangan dan kemajuan siswa berkenaan dengan penguasaan bahan pelajaran yang disajikan kepada siswa.

Kecerdasan ini merupakan salah satu faktor yang berpengaruh dalam proses belajar peserta didik. Penelitian ini lebih menekankan pada proses pengembangan intrapersonal intelegent, mathematical intelegent dan linguistic intelegent. Hal ini didasarkan karena perkembangan belajar peserta didik pada perguruan tinggi menekankan pada proses belajar yang efektif dan bermakna. Dengan mengetahui ke-tiga kecerdasan tersebut, peserta didik dapat mendiagnosik hal apa saja yang perlu dibenahi dalam proses belajar sehingga membuat proses belajar menjadi efektif serta mampu mengolah pola pemikiran yang panjang dan dapat memecahkan permasalahan secara logis.

\section{METODE}

Tipe penelitian yang digunakan merupakan penelitian penjelasan (explanatory research) yang berusaha untuk menjelaskan serta melihat hubungan antar variabel-variabel yang terdapat dalam penelitian serta menjelaskan pengaruh variabel bebas terhadap variabel terikat, di samping itu untuk menguji hipotesis yang diajukan, yang telah dirumuskan sebelumnya.

Populasi dalam penelitian ini adalah seluruh mahasiswa jurusan pendidikan sejarah dan sosiologi. Sampel adalah bagian dari jumlah dan karakteristik yang dimiliki oleh populasi tersebut. Sampel yang diambil harus representatif, artinya harus benar-benar mewakili. (Sugiyono,2010:73). Sampel dalam penelitian ini adalah mahasiswa jurusan sejarah dan sosiologi angkatan 2014.Teknik pengambilan sampel menggunakan probability sampling merupakan cara pengambilan sampel yang pengambilannya dilakukan secara acak atau random yaitu pengambilan sampel dengan pertimbangan tertentu. Dikatakan dengan pertimbangan tertentu karena sampel yang diambil adalah mahasiswa yang belajar pada IKIP Budi Utomo Malang. Berdasarkan jenis dan sumber data yang dikumpulkan, maka digunakan teknik pengumpulan data adalah menggunakan kuesioner, wawancara dan observasi. Sedangkan jenis datanya adalah menggunakan data primer dan data sekunder.

Dalam penelitian ini objek penelitiannya terdiri dari dua variabel yaitu variabel independen dan variabel dependen. Variabel independen adalah sejumlah gejala dengan berbagai unsur atau faktor yang didalamnya menentukan / mempengaruhi adanya variabelvariabel yang lain, yaitu : kecerdasan logistik, intrapersona dan interpersonal. Sedangkan Variabel dependen adalah sejumlah gejala dengan berbagai unsur / faktor didalamnya yang ada ditentukan / dipengaruhi oleh adanya variabel lain, yaitu prestasi belajar.

Definisi operasional adalah definisi yang diberikan kepada suatu variabel atau konstruk dengan cara memberi arti, atau menspesifikasikan kejelasan, ataupun 
memberikan suatu operasional yang variabel tersebut (Sugiyono, 2010: 132) diperlukan untuk mengukur konstruk atau

Tabel 1

Definisi Operasional dan Variabel

\begin{tabular}{|c|c|c|c|}
\hline No & Variabel & Definisi Operasional & Indikator \\
\hline 1. & $\begin{array}{l}\text { Kecerdasan } \\
\text { linguistik } \\
\left(\mathrm{X}_{1}\right)\end{array}$ & $\begin{array}{l}\text { Kecerdasan yang ditunjukkan dengan } \\
\text { kepekaan seseorang pada bunyi, } \\
\text { struktur, makna, fungsi kata, dan } \\
\text { bahasa. }\end{array}$ & $\begin{array}{l}\text { - } \text { Berkomunikasi lisan } \\
\text { - Diskusi dan debat } \\
\text { - Kaya kosa kata } \\
\text { - Membaca dengan } \\
\text { pemahaman tinggi }\end{array}$ \\
\hline 2. & $\begin{array}{l}\text { Kecerdasan } \\
\text { Logic }\left(\mathrm{X}_{2}\right)\end{array}$ & $\begin{array}{l}\text { Kecerdasan yang ditandai dengan } \\
\text { kepekaan pada pola-pola logis dan } \\
\text { memiliki kemampuan mencerna } \\
\text { pola-pola tersebut, termasuk juga } \\
\text { numerik serta mampu mengolah alur } \\
\text { pemikiran yang panjang. }\end{array}$ & $\begin{array}{l}\text { - Memperkirakan fungsi-fungsi } \\
\text { dan hubungan } \\
\text { - Bereksperimen } \\
\text { - Mencari jalan keluar yang } \\
\text { logis } \\
\text { - Berpikir secara abstrak }\end{array}$ \\
\hline 3. & $\begin{array}{l}\text { Kecerdasan } \\
\text { Intrapersona } \\
1\left(\mathrm{X}_{3}\right)\end{array}$ & $\begin{array}{l}\text { Kecerdasan yang ditandai dengan } \\
\text { kemampuan mencerna dan merespon } \\
\text { secara tepat } \\
\text { suasana hati, temperamen, motivasi, } \\
\text { dan keinginan orang lain. }\end{array}$ & $\begin{array}{l}\text { - } \text { Berkomunikasi } \\
\text { - } \text { Memimpin dan } \\
\text { mengorganisasikan kelompok } \\
\text { - } \text { Kerjasama dalam tim }\end{array}$ \\
\hline 4. & $\begin{array}{l}\text { Kecerdasan } \\
\text { Interpersona } \\
1\left(\mathrm{X}_{4}\right)\end{array}$ & $\begin{array}{l}\text { Kecerdasan yang ditandai dengan } \\
\text { kemampuan memahami perasaan } \\
\text { sendiri dan kemampuan } \\
\text { membedakan emosi; pengetahuan } \\
\text { tentang kekuatan dan kelemahan diri. }\end{array}$ & $\begin{array}{l}\text { - Memotivasi diri } \\
\text { - Mematok tujuan diri } \\
\text { - Mengetahui kekuatan dan } \\
\text { kelemahan diri }\end{array}$ \\
\hline 5 . & $\begin{array}{l}\text { Prestasi } \\
\text { Belajar (Y) }\end{array}$ & $\begin{array}{l}\text { Hasil atau taraf kemampuan yang } \\
\text { telah dicapai siswa setelah mengikuti } \\
\text { proses belajar mengajar dalam waktu } \\
\text { tertentu baik berupa perubahan } \\
\text { tingkah laku, keterampilan dan } \\
\text { pengetahuan dan kemudian akan } \\
\text { diukur dan dinilai yang kemudian } \\
\text { diwujudkan dalam angka atau } \\
\text { pernyataan. }\end{array}$ & $\begin{array}{l}\text { - Pengetahuan } \\
\text { - Pemahaman } \\
\text { - Penerapan } \\
\text { - Analisis } \\
\text { - Sintesis } \\
\text { - Evaluasi }\end{array}$ \\
\hline
\end{tabular}

Peneliti yang menggunakan instrumen yang disusun sendiri tidak dapat melepaskan diri dari tanggungjawab uji coba instrumennya, agar apabila digunakan untuk mengumpulkan data, instrumen tersebut sudah betul-betul baik. Tujuan uji coba ini adalah diperolehnya informasi mengenai kualitas instrumen yang digunakan, yaitu informasi mengenai sudah dan belumnya instrumen yang bersangkutan memenuhi persyaratan. Instrumen dapat dikatakan memenuhi persyaratan sebagai alat pengumpul data adalah apabila sekurang-kurangnya instrumen tersebut valid dan reliable (Arikunto, 2006:72). Maka diperlukan uji validitas dan reliabilitas untuk menguji coba instrumen 
penelitian. Teknik analisis data menggunakan analisa kualitatif dan analisa kuantitatif. Alat analisa yang digunakan adalah Regresi linier sederhana, analisis regresi ganda, pengujian hipotesis,

\section{HASIL DAN PEMBAHASAN}

IKIP Budi Utomo Malang berdiri tahun 1984 . Kehadiran perguruan IKIP Budi Utomo Malang ini bersamaan dengan semakin tingginya kebutuhan terhadap guru yang profesional. Saat ini IKIP Budi Utomo Malang satu-satunya perguruan tinggi berbasis kependidikan dan keguruan di Malang Raya. Selain itu sejak diberlakukan akreditasi, IKIP Budi Utomo Malang mencatat prestasi sebagai perguruan tinggi swasta (PTS) kependidikan pertama di Jawa Timur yang mendapatkan status terakreditasi. Selanjutnya 4 tahun kemudian tepatnya tahun 2002, IKIP Budi Utomo Malang kembali mendapatkan status terakreditasi dari Badan Akreditasi Nasional Perguruan Tinggi (BAN-PT). Sehingga saat ini status terakreditasi rata-rata program studi diselenggarakan IKIP Budi Utomo Malang mendapatkan nilai B.

Pada tahun 2009 IKIP BUdi Utomo Malang mendapatkan penghargaan dari Kopertis Wil. VII sebagai Perguruan Tinggi Berprestasi di Bidang Penelitian dan Pengabdian Masyarakat serta berprestasi di bidang Tata Kelola. Selain itu, 5 tahun terakhir mahasiswa IKIP Budi Utomo meraih berbagai penghargaan di beberapa cabang Olahraga (Sepakbola, Bola Volly, Panjat Tebing, dll) baik ditingkat Nasional maupun ditingkat Regional.

Adapun saat ini jumlah program studi yang diselenggarakan IKIP Budi Utomo Malang sebanyak 7 program studi dengan jenjang pendidikan sarjana strata satu (S-1), yaitu program studi Pendidikan Bahasa
Inggris, Pendidikan Bahasa dan Sastra Indonesia, Pendidikan Matematika, Pendidikan Ekonomi dan Kewirausahaan, Pendidikan Biologi, Pendidikan Jasmani Kesehatan dan Rekreasi, dan Pendidikan Sejarah dan Sosiologi

Dalam pembahasan statistik deskriptif ini untuk mendapatkan gambaran mengenai responden, berikut ini diuraikan pengelompokan responden berdasarkan jenis kelamin responden, usia responden dan indeks prestasi. Adapun data yang peneliti peroleh mengenai profil responden adalah sebagai berikut.

\section{Tabel 2}

\section{Karakteristik Responden Berdasarkan Jenis Kelamin}

\begin{tabular}{|l|c|c|}
\hline Jenis Kelamin & Jumlah & Presentase \\
\hline Pria & 33 & 41,25 \\
\hline Wanita & 47 & 58,75 \\
\hline \multicolumn{1}{|c|}{ Total } & $\mathbf{8 0}$ & $\mathbf{1 0 0}$ \\
\hline
\end{tabular}

Berdasarkan table 2 di atas, total responden yang merupakan mahasiswa jurusan sejarah IKIP Budi Utomo Malang adalah 80 orang, jumlah responden pria sebanyak 33 orang $(41,25 \%)$ dan responden wanita sebanyak 47 orang $(58,75 \%)$, maka dapat diketahui bahwa mayoritas responden adalah wanita. Dari data tersebut terlihat komposisi mahasiswa berdasarkan jenis kelamin tidak seimbang, akan tetapi hal ini tidak berpengaruh terhadap minat mahasiswa karena sudah mulai nampak kesetaraan jender.

Dalam uji validitas, setiap item variabel akan diuji validitasnya, untuk mengetahui validitas setiap item pertanyaan dalam instrumen penelitian dapat dilihat melalui kolom Corrected item-total correlation. Jika nilai Corrected item-total correlation lebih besar dari $r$ tabel atau $>0,312$ maka pernyataan tersebut dinyatakan valid. 
Tabel 3

Uji Validitas Kecerdasan Linguistik (X1)

\begin{tabular}{|c|c|c|c|}
\hline Butir soal & & & Keputusan \\
\hline 1 & 0,456 & 0,312 & Valid \\
\hline 2 & 0,593 & 0,312 & Valid \\
\hline 3 & 0,163 & 0,312 & Tidak valid \\
\hline 4 & 0,415 & 0,312 & Valid \\
\hline 5 & 0,131 & 0,312 & Tidak valid \\
\hline 6 & 0,503 & 0,312 & Valid \\
\hline 7 & $-0,060$ & 0,312 & Tidak valid \\
\hline 8 & 0,593 & 0,312 & Valid \\
\hline 9 & 0,618 & 0,312 & Valid \\
\hline
\end{tabular}

Tabel 4

Uji Validitas Kecerdasan Logic (X2)

\begin{tabular}{|l|l|l|l|}
\hline Butir soal & & & Keputusan \\
\hline 1 & 0,458 & 0,312 & Valid \\
\hline 2 & 0,189 & 0,312 & Tidak valid \\
\hline 3 & 0,565 & 0,312 & Valid \\
\hline 4 & 0,345 & 0,312 & Valid \\
\hline 5 & 0,239 & 0,312 & Tidak valid \\
\hline 6 & 0,422 & 0,312 & Valid \\
\hline 7 & 0,350 & 0,312 & Valid \\
\hline 8 & 0,504 & 0,312 & Valid \\
\hline 9 & 0,535 & 0,312 & Valid \\
\hline
\end{tabular}

Tabel 5

Uji Validitas Kecerdasan Intrapersonal (X3)

\begin{tabular}{|l|l|l|l|}
\hline Butir soal & & & Keputusan \\
\hline 1 & 0,072 & 0,312 & Tidak valid \\
\hline 2 & 0,695 & 0,312 & Valid \\
\hline 3 & 0,440 & 0,312 & Valid \\
\hline 4 & 0,573 & 0,312 & Valid \\
\hline 5 & 0,223 & 0,312 & Tidak valid \\
\hline 6 & 0,703 & 0,312 & Valid \\
\hline 7 & 0,298 & 0,312 & Tidak valid \\
\hline
\end{tabular}


Tabel 6

Uji Validitas Prestasi Belajar (X3)

\begin{tabular}{|c|c|c|c|}
\hline Butir soal & & & Keputusan \\
\hline 1 & 0,151 & 0,312 & Tidak valid \\
\hline 2 & 0,765 & 0,312 & Valid \\
\hline 3 & 0,577 & 0,312 & Valid \\
\hline 4 & 0,673 & 0,312 & Valid \\
\hline 5 & 0,434 & 0,312 & Valid \\
\hline 6 & 0,282 & 0,312 & Tidak valid \\
\hline 7 & 0,071 & 0,312 & Tidak valid \\
\hline 8 & 0,028 & 0,312 & Tidak valid \\
\hline 9 & 0,537 & 0,312 & Valid \\
\hline 10 & 0,444 & 0,312 & Valid \\
\hline 11 & 0,101 & 0,312 & Tidak valid \\
\hline 12 & 0,292 & 0,312 & Tidak valid \\
\hline 13 & 0,433 & 0,312 & Valid \\
\hline 14 & 0,367 & 0,312 & Valid \\
\hline 15 & 0,576 & 0,312 & Valid \\
\hline 16 & 0,612 & 0,312 & Valid \\
\hline 17 & 0,433 & 0,312 & Valid \\
\hline 18 & 0,407 & 0,312 & Valid \\
\hline 19 & 0,038 & 0,312 & Tidak valid \\
\hline 20 & 0,660 & 0,312 & Valid \\
\hline 21 & 0,434 & 0,312 & Valid \\
\hline 22 & $-0,029$ & 0,312 & Tidak valid \\
\hline 23 & 0,660 & 0,312 & Valid \\
\hline 24 & 0,014 & 0,312 & Tidak valid \\
\hline 25 & 0,418 & 0,312 & Valid \\
\hline
\end{tabular}

Uji reliabilitas dilakukan dengan uji dikatakan reliabel atau dapat dianalisis lebih Alpha Cronbach. Apabila nilai Alpha lanjut. Berikut ini akan disajikan table hasil Chronbach lebih besar dari 0,5 maka dapat perhitungan reliabilitas setiap variable.

Tabel 7

Hasil Uji Reliabilitas

\begin{tabular}{|c|l|c|}
\hline No & \multicolumn{1}{|c|}{ Variabel } & Alpha Cronbach \\
\hline 1. & Kecerdasan linguistic (X1) & 0,693 \\
\hline 2. & Kecerdasan logic (X2) & 0,722 \\
\hline 3. & Kecerdasan intrapersonal (X3) & 0,700 \\
\hline 4. & Prestasi belajar (Y) & 0,833 \\
\hline
\end{tabular}


Rahadian, Pengaruh Multiple Intelligences Terhadap $\neg$ Prestasi Belajar Mahasiswa 65

Pengujian hipotesis dalam penelitian yaitu: kecerdasan linguistic, kecerdasan logic, ini menggunakan regresi linier berganda, dan kecerdasan intrapersonal dan variabel analisis ini dimaksudkan untuk mengetahui prestasi belajar mahasiswa sebagai variabel pengaruh variabel-variabel bebas (independen) terikat atau yang dipengaruhi (dependen).

Tabel 8

Hasil Uji Regresi Berganda

\begin{tabular}{|l|l|l|l|l|}
\hline Variabel & $\mathbf{b}$ & $\mathbf{t}_{\text {hitung }}$ & Sig & Kesimpulan \\
\hline Konstan & 10,443 & & $\begin{array}{l}\text { Tidak } \\
\text { berpengaruh }\end{array}$ \\
\hline $\mathrm{X}_{1}$ & 0,30 & 0,28 & $\begin{array}{l}0,78 \\
1\end{array}$ & $\begin{array}{l}\text { Tidak } \\
\text { berpengaruh }\end{array}$ \\
\hline $\mathrm{X}_{2}$ & $-0,258$ & $-0,449$ & $\begin{array}{l}0,02 \\
4\end{array}$ & $\begin{array}{l}\text { Tidak } \\
\text { berpengaruh }\end{array}$ \\
\hline $\mathrm{X}_{3}$ & 0,098 & 0,112 & $\begin{array}{l}0,55 \\
7\end{array}$ & $\begin{array}{l}\text { Tidak } \\
\text { berpengaruh }\end{array}$ \\
\hline $\mathrm{F}$ & & 1,974 & $\begin{array}{l}0,13 \\
8\end{array}$ & $\begin{array}{l}\text { Tidak } \\
\text { berpengaruh }\end{array}$ \\
\hline $\mathrm{R}^{2}$ & & 0,401 & & \\
\hline
\end{tabular}

Tujuan dari uji Normalitas adalah untuk mengetahui apakah dalam sebuah model regresi, variabel bebas dan terikatnya atau keduanya mempunyai distribusi normal atau tidak. Model regresi yang baik adalah berdistribusi data normal atau mendekati normal.

Tabel 9

Uji Kolmogorov-Smirnof

\begin{tabular}{|c|c|c|c|c|}
\hline Variabel & $\mathbf{Z}$ & $\begin{array}{c}\text { Probability } \\
\text { (p) }\end{array}$ & Kriteria & Kesimpulan \\
\hline Kec. Linguistic $\left(\mathrm{X}_{1}\right)$ & 0,698 & 0,714 & \multirow{4}{*}{$\begin{array}{c}\mathrm{P}>\alpha \\
0,05\end{array}$} & \multirow{4}{*}{$\begin{array}{l}\text { Data } \\
\text { Berdistribusi } \\
\text { Normal }\end{array}$} \\
\hline Kec. Logic $\left(\mathrm{X}_{2}\right)$ & 1,055 & 0,215 & & \\
\hline Kec. Intra personal $\left(\mathrm{X}_{3}\right)$ & 1,227 & 0,099 & & \\
\hline Prestasi (Y) & 0,862 & 0,447 & & \\
\hline
\end{tabular}

Dari tabel diatas diketahui bahwa nilai signifikansi atau probabilitas semua variabel $>$ 0,05 maka dapat disimpulkan bahwa seluruh variabel penelitian mempunyai sebaran data berdistribusi normal.

Uji multikol bertujuan untuk menguji apakah model regresi ditemukan adanya korelasi antar variabel bebas (independen). Model regresi yang baik seharusnya tidak terjadi korelasi di antlineritasara variabel independen. Jika variabel independen saling berkorelasi, maka variabel-variabel ini tidak ortogonal (Ghozali 2007:91). Untuk mendeteksi adanya multikolinearitas, dapat dilihat dari Value Inflation Factor (VIF). Apabila nilai VIF $>10, \quad$ terjadi multikolinieritas. Sebaliknya, jika VIF $<10$, tidak terjadi multikolinearitas (Wijaya, 2009:119). 
Tabel 10

Hasil Uji Multikolinieritas

\begin{tabular}{|l|l|l|l|}
\hline No. & Variabel & Nilai VIF & Kesimpulan \\
\hline 1 & Kec. Linguistic $\left(\mathrm{x}_{1}\right)$ & 1,090 & Tidak ada Multikolineritas \\
\hline 2 & Kec. Logic $\left(\mathrm{x}_{2}\right)$ & 1,329 & Tidak ada Multikolineritas \\
\hline 3 & Kec. Intra personal $\left(\mathrm{x}_{3}\right)$ & 1,302 & Tidak ada Multikolineritas \\
\hline
\end{tabular}

Sumber: Hasil pengolahan SPSS 20

Analisis koefisien Determinasi (R) ini digunakan untuk mengetahui seberapa besar sumbangan yang diberikan variable bebas terhadap variable terikat yang ditunjukkan dengan persentase. Dari hasil analisis data diperoleh $\mathrm{R}^{2}$ sebesar 0,079 ini menunjukkan bahwa variable kecerdasan linguistic, logic dan intrapersonal mempunyai kontribusi pengaruh terhadap variable prestasi belajar sebesar $7,9 \%$ dan sisanya sebesar $92,1 \%$ dipengaruhi oleh variable lain yang tidak diteliti.

Uji $\mathrm{t}$ dilakukan untuk membuktikan bahwa koefisien regresi suatu model itu statistik signifikan atau tidak, maka dipakai uji t.

Berdasarkan hasil analisis data yang telah dilakukan di SPSS maka diketahui bahwa thitung variabel kecerdasan linguistik adalah sebesar 0,28 dengan taraf signifiknsi 0,05. Sehingga dapat disimpulkan bahwa nilai $t_{\text {hitung }}$ $<t_{\text {tabel }}(0,28<2,309)$, maka untuk variabel kecerdasan linguistik $\left(\mathrm{X}_{1}\right)$ hipotesis $\mathrm{H}_{0}$ diterima artinya bahwa kecerdasan linguistik tidak berpengaruh terhadap prestasi belajar (Y). Berdasarkan hasil analisis data yang telah dilakukan di SPSS maka diketahui bahwa

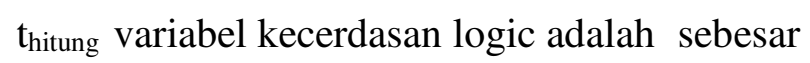
$-2,368$ dengan taraf signifiknsi 0,05 . Sehingga dapat disimpulkan bahwa nilai $\mathrm{t}_{\text {hitung }}<\mathrm{t}_{\text {tabel }}$ ($2,368<2,309$ ), maka untuk variabel kecerdasan logic $\left(\mathrm{X}_{2}\right)$ hipotesis $\mathrm{H}_{0}$ diterima artinya bahwa kecerdasan logic tidak berpengaruh terhadap prestasi belajar (Y).

Berdasarkan hasil analisis data yang telah dilakukan di SPSS maka diketahui bahwa $t_{\text {hitung variabel kecerdasan intra personal adalah }}$ sebesar 0,594 dengan taraf signifiknsi 0,594. Sehingga dapat disimpulkan bahwa nilai $t_{\text {hitung }}$ $<t_{\text {tabel }}(0,594<2,309)$, maka untuk variabel kecerdasan logic $\left(\mathrm{X}_{3}\right)$ hipotesis $\mathrm{H}_{0}$ diterima artinya bahwa kecerdasan intra personal tidak berpengaruh terhadap prestasi belajar (Y). Uji $F$ digunakan dalam penelitian ini untuk mengetahui pengaruh antar variabel yaitu variabel bebas dan terikat secara bersamasama. Berdasarkan hasil perhitungan dengan menggunakan program SPSS dengan taraf signifikansi 0,05 diperoleh Fhitung sebesar 1,974. Dengan membandingkan nilai $F_{\text {hitung }}$ dengan nilai $\mathrm{F}_{\text {tabel }}(1,974<2,91)$ dan nilai probabilitas sebesar 0,138>0,05 maka variabel kecerdasan linguistic, logic dan intra personal secara bersama-sama atau serentak tidak berpengaruh secara signifikan terhadap prestasi belajar.

Berdasarkan pengolahan dan analisa data yang telah dilakukan, hasil penelitian ini menyimpulkan Tidak terdapat pengaruh yang signifikan antara kecerdasan linguistic, logic dan intra personal terhadap prestasi belajar mahasiswa IKIP Buid Utomo Malang. Hal ini ditunjukkan berdasarkan hasil uji $\mathrm{F}$ dengan nilai $\mathrm{F}_{\text {hitung }}<\mathrm{F}_{\text {tabel }}(1,974<2,91)$, dan nilai probabilitas sebesar $0,138>0,05$ maka variabel kecerdasan linguistic, logic dan intra personal secara bersama-sama atau serentak tidak berpengaruh secara signifikan terhadap prestasi belajar mahasiswa IKIP Budi Utomo Malang.

Tidak terdapat pengaruh yang signifikan antara kecerdasan linguistic terhadap prestasi belajar mahasiswa. Untuk variabel kecerdasan linguistic diperoleh nilai $t_{\text {hitung }}<\mathrm{t}_{\text {tabel }}(0,28<$ 2,309), maka untuk kecerdasan linguistik $\left(\mathrm{X}_{1}\right)$ 
hipotesis H0 diterima dengan asumsi bahwa kecerdasan linguistic tidak memberikan berpengaruh secara signifikan terhadap prestasi belajar (Y). Kecerdasan linguistik merupakan kecerdasan yang ditunjukkan dengan kepekaan seseorang pada bunyi, struktur, makna, fungsi kata dan bahasa. Terdapat beberapa faktor yang mempengaruhi kecerdasan linguistik dalam penelitian ini diantaranya kemampuan dalam berkomunikasi, kemampuan dalam berdiskusi, kaya kosa kata serta mampu membaca dengan pemahaman tinggi. Apabila mahasiswa mampu untuk mengaplikasikan faktor-faktor tersebut kedalam proses belajar dikelas maka kecerdasan linguistik dapat terus berkembang dengan baik dan hal ini akan berpengaruh terhadap prestasi belajar mahasiswa. Namun permasalahan yang timbul disini adalah lemahnya tingkat analis kemampuan mahasiswa dalam menganalisis sebuah permasalahan. Hal ini terlihat ketika terjadi diskusi kelompok. Mayoritas mahasiswa hanya bertanya alakadarnya ataupun bertanya sebagai formalitas. Apabila hal ini terus dibiarkan maka kecerdasan linguistik mahasiswa tidak dapat berkembang degan maksimal.

Tidak terdapat pengaruh yang signifikan antara kecerdasan logic terhadap prestasi belajar mahasiswa IKIP Budi Utomo Malang pada variabel kecerdasan logic diperoleh nilai $t_{\text {hitung }}<t_{\text {tabel }}(-2,368<2,309)$, maka untuk variable kecerdasan logic $\left(\mathrm{X}_{2}\right)$ hipotesis $\mathrm{H} 0$ diterima artinya bahwa kecerdasan logic tidak berpengaruh secara signifikan terhadap prestasi belajar (Y). Kecerdasan logik merupakan kecerdasan yang ditandai dengan kepekaan pada pola-pola logis dan memiliki kemampuan mencerna pola-pola tersebut, termasuk juga numerik serta mampu mengolah alur pemikiran yang panjang. Kecerdasan logik ini dipengari oleh beberpa faktor diantaranya, memperkirakan fungsi-fungsi dan hubungan, bereksperimen, mencari jalan keluar yang logis serta berpikir secara abstrak.

Dalam penelitian ini kecerdasan logik tidak nampak dalam memberikan pengaruh terhadap prestasi belajar. Hal ini dikarenakan kemampuan mahasiswa dalam menyusun sebuah pemikiran yang abstrak dan menghubungkannya dengan pemikiran yang logis masih lemah. Mayoritas mahasiswa masih kesulitan dalam memecahkan sebuah permasalahan yang bersifat analisis. Hal ini terlihat ketika mahasiswa diberikan sebuah soal analisis, cara mereka dalam menyelesaikan sebuah masalah tersebut terkadang keluar dari konteks permasalahan yang dibahas. Apabila tidak segera teratasi tentunya akan berpengaruh terhadap perkembangan kecerdasan serta prestasi belajarnya.

Tidak terdapat pengaruh yang signifikan antara kecerdasan intra personal terhadap prestasi belajar mahasiswa IKIP Budi Utomo. Pada variabel kecerdasan intra personal diperoleh nilai $t_{\text {hitung }}<\mathrm{t}_{\text {tabel }}(0,594<2,309)$, maka untuk variable kecerdasan intra personal $\left(\mathrm{X}_{3}\right)$ hipotesis $\mathrm{H} 0$ diterima artinya bahwa kecerdasan intra personal tidak berpengaruh secara signifikan terhadap prestasi belajar (Y). Kecerdasan intrapersonal adalah sebuah kecerdasan yag ditandai dengan kemampuan mencerna dan merespon secara tepat suasana hati, tempramen, motivasi dan keinginan orang lain. Adapun faktor-faktor yang mempengaruhi kecerdasan ini adalah berkomunikasi, memimpin dan mengorganisasikan kelompok serta kerjasama dalam tim.

Dalam penelitian ini pengaruh kecerdasan intrapersonal tidak nampak atupun tidak mempengaruhi prestasi belajar mahasiswa. Hal ini dikarenakan sikap kurang menghargai yang masih nampak diantara beberapa mahasiswa dan ini yang dapat mengancam persatuan dan kesatuan yang terbentuk dalam satu wadah yang dikenal 
sebagai keluarga besar IBU. Pengujian hipotesis menunjukkan tidak terdapat pengaruh yang positif dan signifikan variabel kecerdasan linguistic, logic dan intra personal terhadap prestasi belajar mahasiswa jurusan Sejarah dan Sosiologi IKIP Budi Utomo. Hasil ini menunjukkan bahwa kemampuan mahasiswa dalam menganalisis kejadian yang terjadi sebuah lingkungan masih terbilang rendah. Kondisi ini dapat terlihat ketika diskusi sedang berlangsung, rata-rata mahasiswa masih acuh dan lebih mengandalkan google baik ketika presentasi maupun mengajukan pertanyaan. Selain itu mahasiswa juga bertanya hanya sekedar sebagai formalitas saja.

Menurut Dalyono (2009) seseorang yang mempunyai intelegensi baik umumnya mudah belajar dan hasilnya pun cenderung baik. Sebaliknya orang yang mempunyai intelegensi rendah cenderung mengalami kesukaran dalam belajar, lambat berpikir sehingga prestasinya cenderung rendah. Hasil ini menunjukkan bahwa kemampuan mahasiswa dalam menganalisis kejadian yang terjadi sebuah lingkungan masih terbilang rendah. Kondisi ini dapat terlihat ketika diskusi sedang berlangsung, rata-rata mahasiswa masih acuh dan lebih mengandalkan google baik ketika presentasi maupun mengajukan pertanyaan. Selain itu mahasiswa juga bertanya hanya sekedar sebagai formalitas saja.

Mayoritas mahasiswa masih kesulitan dalam mengembangkan pemahaman yang mereka miliki sehingga pola pikir mereka tidak dapat terbentuk dengan baik. Akibatnya mereka akan kesulitan ketika mendapatkan soal yang berbentuk analisis karena logika mereka tidak berjalan dengan baik. Banyak mahasiswa yang masih belum bisa membaca suasana hati dari temannya yang terkadang dapat menimbulkan konflik. Kemampuan mahasiswa dalam memotivasi dirinya juga masih kurang sehingga respon mereka ketika menerima kuliah dari para dosen menjadi acuh tak acuh. Karena mereka masih berfikir kuliah cuma datang dan duduk yang penting berangkat pasti akan mendapatkan nilai yang bagus. Tentunya hal inilah yang harus dibenahi agar dapat menciptakan lulusan yang berkompeten dan kepekaan yang tinggi terhadap kondisi sosial disekitar.

Komunikasi yang efektif ditandai dengan hubungan sosial yang baik (Moekijat 1984:33). Kegagalan komunikasi terjadi bila isi pesan kita dipahami, tetapi hubungan diantara komunikan menjadi rusak. Komunikasi interpersonal dinyatakan efektif bila pertemuan komunikasi merupakan hal yang menyenangkan bagi komunikan. Bila kita berkumpul dengan orang yang menyenangkan maka akan terjadi komunikasi yang menyenangkan. Setiap melakukan komunikasi interpersonal, kita tidak hanya sekedar menyampaikan isi pesan, tetapi juga menentukan kadar hubungan interpersonal. Perlahan-lahan studi komunikasi interpersonal bergeser dari isi pesan pada aspek relasional. Makin baik hubungan interpersonal maka akan terjadi hal-hal seperti, makin terbuka seseorang mengungkapkan perasaannya, cenderung meneliti perasaannya secara mendalam, serta cenderung mendengar dengan penuh perhatian dan bertindak. Makin baik hubungan seseorang makin terbuka seseorang untuk mengungkapkan dirinya, makin cermat persepsinya tentang orang lain dan persepsi dirinya, sehingga makin efektif komunikasi yang berlangsung diantara komunikan.

Prestasi belajar tidak dapat dipisahkan dari berbuatan belajar, karena belajar merupakan suatu proses, sedangkan prestasi belajar adalah hasil dari proses pembelajaran tersebut. Bagi seorang mahasiswa belajar merupakan suatu kewajiban. Berhasil atau tidaknya seorang mahasiswa dalam pendidikan tergantung pada proses belajar yang dialami oleh siswa tersebut. Menurtut Logan, dkk (1976) dalam Sia Tjundjing (2001:70) belajar dapat diartikan sebagai perubahan tingkah laku 
yang relatif menetap sebagai hasil pengalaman dan latihan. Senada dengan hal tersebut, Winkel (1997:193) berpendapat bahwa belajar pada manusia dapat dirumuskan sebagai suatu aktivitas mental atau psikis yang berlangsung dalam interaksi aktif dengan lingkungan, yang menghasilkan perubahan-perubahan dalam pengetahuan dan nilai sikap. Perubahan itu bersifat relatif konstan dan berbekas.

Belajar tidak hanya dapat dilakukan di kampus saja, namun dapat dilakukan dimanamana, seperti di rumah ataupun dilingkungan masyarakat. Irwanto (1997:105) berpendapat bahwa belajar merupakan proses perubahan dari belum mampu menjadi sudah mampu dan terjadi dalam jangka waktu tertentu. Sedangkan menurut Mudzakir (1997:34) belajar adalah suatu usaha atau kegiatan yang bertujuan mengadakan perubahan di dalam diri seseorang, mencakup perubahan tingkah laku, sikap, kebiasaan, ilmu pengetahuan, keterampilan dan sebagainya. Di dalam belajar, mahasiswa mengalami sendiri proses dari tidak tahu menjadi tahu, karena itu menurut Cronbach (Sumadi Suryabrata,1998:231) belajar yang sebaikbaiknya adalah dengan mengalami dan dalam mengalami itu pelajar mempergunakan pancainderanya. Pancaindera tidak terbatas hanya indera pengelihatan saja, tetapi juga berlaku bagi indera yang lain. Belajar dapat dikatakan berhasil jika terjadi perubahan dalam diri mahasiswa, namun tidak semua perubahan perilaku dapat dikatakan belajar karena perubahan tingkah laku akibat belajar memiliki ciri-ciri perwujudan yang khas (Muhibbidin Syah, 2000:116). Diantara perubahan tersebut adalah perubahan intensional. Perubahan intensional adalah perubahan dalam proses berlajar adalah karena pengalaman atau praktek yang dilakukan secara sengaja dan disadari. Pada ciri ini mahasiswa menyadari bahwa ada perubahan dalam dirinya, seperti penambahan pengetahuan, kebiasaan dan keterampilan.
Perubahan berikutnya adalah Perubahan Positif dan aktif. Perubahan Positif berarti perubahan tersebut baik dan bermanfaat bagi kehidupan serta sesuai dengan harapan karena memperoleh sesuatu yang baru, yang lebih baik dari sebelumnya. Sedangkan aktif artinya perubahan tersebut terjadi karena adanya usaha dari mahasiswa yang bersangkutan.

Terakhir perubahan tingkah laku akibat belajar adalah belajar efektif dan fungsional. Perubahan dikatakan efektif apabila membawa pengaruh dan manfaat tertentu bagi mahasiswa. Sedangkan perubahan yang fungsional artinya perubahan dalam diri mahasiswa tersebut relatif menetap dan apabila dibutuhkan perubahan tersebut dapat direproduksi dan dimanfaatkan lagi. Berdasarkan dari uraian di atas, maka dapat disimpulkan bahwa belajar adalah suatu proses usaha yang dilakukan mahasiswa untuk memperoleh suatu perubahan tingkah laku yang baru secara keseluruhan, secara sengaja, disadari dan perubahan tersebut relatif menetap serta membawa pengaruh dan manfaat yang positif bagi mahasiswa dalam berinteraksi dengan lingkungannya.

Untuk mendapatkan suatu prestasi tidaklah semudah yang dibayangkan, karena memerlukan perjuangan dan pengorbanan dengan berbagai tantangan yang harus dihadapi. Penilaian terhadap hasil belajar mahasiswa untuk mengetahui sejauhmana ia telah mencapai sasaran belajar inilah yang disebut sebagai prestasi belajar. Seperti yang dikatakan oleh Winkel (1997:168) bahwa proses belajar yang dialami oleh mahasiswa menghasilkan perubahan-perubahan dalam bidang pengetahuan dan pemahaman, dalam bidang nilai, sikap dan keterampilan. Adanya perubahan tersebut tampak dalam prestasi belajar yang dihasilkan oleh mahasiswa terhadap pertanyaan, persoalan atau tugas yang diberikan oleh dosen. Melalui prestasi belajar mahasiswa dapat mengetahui kemajuankemajuan yang telah dicapainya dalam belajar. 
Sedangkan Marsun dan Martaniah dalam Sia Tjundjing (2000:71) berpendapat bahwa prestasi belajar merupakan hasil kegiatan belajar, yaitu sejauh mana peserta didik menguasai bahan pelajaran yang diajarkan, yang diikuti oleh munculnya perasaan puas bahwa ia telah melakukan sesuatu dengan baik. Hal ini berarti prestasi belajar hanya bisa diketahui jika telah dilakukan penilaian terhadap hasil belajar mahasiswa. Menurut Poerwodarminto (Mila Ratnawati, 1996 : 206) yang dimaksud dengan prestasi adalah hasil yang telah dicapai, dilakukan atau dikerjakan oleh seseorang. Sedangkan prestasi belajar itu sendiri diartikan sebagai prestasi yang dicapai oleh seorang mahasiswa pada jangka waktu tertentu dan dicatat dalam buku rapor sekolah.

Dari beberapa definisi di atas, dapat ditarik kesimpulan bahwa prestasi belajar merupakan hasil usaha belajar yang dicapai seorang mahasiswa/peserta didik berupa suatu kecakapan dari kegiatan belajar bidang akademik di kampus/sekolah pada jangka waktu tertentu yang dicatat pada setiap akhir semester di dalam buki laporan yang disebut kartu hasil studi. Untuk meraih prestasi belajar yang baik, banyak sekali faktor yang perlu diperhatikan, karena di dalam dunia pendidikan tidak sedikit mahasiswa yang mengalami kegagalan. Kadang ada mahasiswa yang memiliki dorongan yang kuat untuk berprestasi dan kesempatan untuk meningkatkan prestasi, tapi dalam kenyataannya prestasi yang dihasilkan di bawah kemampuannya.

Untuk meraih prestasi belajar yang baik banyak sekali faktor-faktor yang perlu diperhatikan. Menurut Sumadi Suryabrata (1998 : 233) dan Shertzer dan Stone (Winkle, 1997 : 591), secara garis besar faktor-faktor yang mempengaruhi belajar dan prestasi belajar dapat digolongkan menjadi dua bagian, yaitu faktor internal dan faktor eksternal. Faktor internal merupakan faktor yang berasal dari dalam diri siswa yang dapat mempengaruhi prestasi belajar. Faktor ini dapat dibedakan menjadi dua kelompok, yaitu faktor fisiologis dan faktor psikologis.

Faktor fisiologis yang dimaksud adalah faktor yang berhubungan dengan kesehatan dan pancaindera seperti kesehatan badan. Untuk dapat menempuh studi yang baik mahasiswa perlu memperhatikan dan memelihara kesehatan tubuhnya. Keadaan fisik yang lemah dapat menjadi penghalang bagi mahasiswa dalam menyelesaikan program studinya. Dalam upaya memelihara kesehatan fisiknya, siswa perlu memperhatikan pola makan dan pola tidur, untuk memperlancar metabolisme dalam tubuhnya. Selain itu, juga untuk memelihara kesehatan bahkan juga dapat meningkatkan ketangkasan fisik dibutuhkan olahraga yang teratur.

Faktor fisiologis selanjutnya adalah pancaindera. Berfungsinya pancaindera merupakan syarat dapatnya belajar itu berlangsung dengan baik. Dalam sistem pendidikan dewasa ini di antara pancaindera itu yang paling memegang peranan dalam belajar adalah mata dan telinga. Hal ini penting, karena sebagian besar hal-hal yang dipelajari oleh manusia dipelajari melalui penglihatan dan pendengaran. Dengan demikian, seorang anak yang memiliki cacat fisik atau bahkan cacat mental akan menghambat dirinya didalam menangkap pelajaran, sehingga pada akhirnya akan mempengaruhi prestasi belajarnya di kampus.

Ada banyak faktor psikologis yang dapat mempengaruhi prestasi belajar mahasiswa, antara lain adalah intelligensi. Pada umumnya, prestasi belajar yang ditampilkan mahasiswa mempunyai kaitan yang erat dengan tingkat kecerdasan yang dimiliki mahasiswa . Menurut Binet (Winkle,1997 :529) hakikat inteligensi adalah kemampuan untuk menetapkan dan mempertahankan suatu tujuan, untuk mengadakan suatu penyesuaian dalam rangka mencapai tujuan itu dan untuk menilai keadaan diri secara kritis dan objektif. Taraf inteligensi 
ini sangat mempengaruhi prestasi belajar seorang mahasiswa, di mana mahasiswa yang memiliki taraf inteligensi tinggi mempunyai peluang lebih besar untuk mencapai prestasi belajar yang lebih tinggi. Sebaliknya, mahasiswa yang memiliki taraf inteligensi yang rendah diperkirakan juga akan memiliki prestasi belajar yang rendah. Namun bukanlah suatu yang tidak mungkin jika mahasiswa dengan taraf inteligensi rendah memiliki prestasi belajar yang tinggi, juga sebaliknya .

Faktor psikologis selanjutnya yang juga mempengarui prestasi belajar mahaiswa adalah sikap. Sikap yang pasif, rendah diri dan kurang percaya diri dapat merupakan faktor yang menghambat mahasiswa dalam menampilkan prestasi belajarnya. Menurut Sarlito Wirawan (1997:233) sikap adalah kesiapan seseorang untuk bertindak secara tertentu terhadap halhal tertentu. Sikap mahasiswa yang positif terhadap mata kuliah di kampus merupakan langkah awal yang baik dalam proses belajar mengajar di kampus. Motivasi juga merupakan aspek yang berpengaruh terhadap prestasi belajar mahasiswa. Menurut Irwanto (1997: 193) motivasi adalah penggerak perilaku. Motivasi belajar adalah pendorong seseorang untuk belajar. Motivasi timbul karena adanya keinginan atau kebutuhan-kebutuhan dalam diri seseorang. Seseorang berhasil dalam belajar karena ia ingin belajar. Sedangkan menurut Winkle (1997 : 39) motivasi belajar adalah keseluruhan daya penggerak di dalam diri mahasiswa yang menimbulkan kegiatan belajar, yang menjamin kelangsungan dari kegiatan belajar dan yang memberikan arah pada kegiatan belajar itu, maka tujuan yang dikehendaki oleh mahasiswa tercapai. Motivasi belajar merupakan faktor psikis yang bersifat non intelektual. Peranannya yang khas ialah dalam hal gairah atau semangat belajar, mahasiswa yang termotivasi kuat akan mempunyai banyak energi untuk melakukan kegiatan belajar.
Faktor eksternal adalah hal-hal lain diluar diri yang dapat mempengaruhi prestasi belajar yang akan diraih oleh peserta didik/mahasiswa. Beberapa diantara faktor eksternal tersebut adalah faktor lingkungan keluarga. Dalam faktor lingkungan keluarga setidaknya ada empat hal yang memberikan pengaruh terhadap prestasi belajar mahasiswa, yang pertama kondisi sosial ekonomi keluarga. Dengan sosial ekonomi yang memadai, seseorang lebih berkesempatan mendapatkan fasilitas belajar yang lebih baik, mulai dari buku, alat tulis hingga pemilihan sekolah

Kedua, Pendidikan orang tua. Orang tua yang telah menempuh jenjang pendidikan tinggi cenderung lebih memperhatikan dan memahami pentingnya pendidikan bagi anakanaknya, dibandingkan dengan yang mempunyai jenjang pendidikan yang lebih rendah. Ketiga, Perhatian orang tua dan suasana hubungan antara anggota keluarga. Dukungan dari keluarga merupakan suatu pemacu semangat berpretasi bagi seseorang. Dukungan dalam hal ini bisa secara langsung, berupa pujian atau nasihat; maupun secara tidak langsung, seperti hubugan keluarga yang harmonis.

Faktor eksternal berikutnya yang juga turut mempengaruhi prestasi belajar mahasiswa adalah faktor lingkungan perkuliahan. Dalam faktor lingkungan perkuliahan ada beberapa hal yang perlu mendapatkan perhatian jika prestasi belajar mahasiswa/peserta didik ingin ditingkatkan. Pertama Sarana dan prasarana. Kelengkapan fasilitas kampus, seperti papan tulis, OHP akan membantu kelancaran proses belajar mengajar di kampus, selain bentuk ruangan, sirkulasi udara dan lingkungan sekitar sekolah juga dapat mempengaruhi proses belajar mengajar

Kedua, Kompetensi dosen dan mahasiswa. Kualitas dosen dan mahasiswa sangat penting dalam meraih prestasi, 
kelengkapan sarana dan prasarana tanpa disertai kinerja yang baik dari para penggunanya akan sia-sia belaka. Bila seorang mahasiswa merasa kebutuhannya untuk berprestasi dengan baik di kampus terpenuhi, misalnya dengan tersedianya fasilitas dan tenaga pendidik yang berkualitas, yang dapat memenihi rasa keingintahuannya, hubungan dengan dosen dan teman-temannya berlangsung harmonis, maka mahasiswa akan memperoleh iklim belajar yang menyenangkan. Dengan demikian, ia akan terdorong untuk terus-menerus meningkatkan prestasi belajarnya.

Ketiga, Kurikulum dan metode mengajar. Hal ini meliputi materi dan bagaimana cara memberikan materi tersebut kepada mahasiswa. Metode pembelajaran yang lebih interaktif sangat diperlukan untuk menumbuhkan minat dan peran serta mahasiswa dalam kegiatan pembelajaran. Sarlito Wirawan (1997:122) mengatakan bahwa faktor yang paling penting adalah faktor tenaga pendidik. Jika tenaga pendidik mengajar dengan arif bijaksana, tegas, memiliki disiplin tinggi, luwes dan mampu membuat mahasiswa menjadi senang akan pelajaran, maka prestasi belajar mahasiswa akan cenderung tinggi, palingtidak mahaiswa tersebut tidak bosan dalam mengikuti perkuliahan.

Keempat, Faktor eksternal berikutnya yang juga turut mempengaruhi prestasi belajar mahasiswa adalah lingkungan masyarakat. Dalam lingkungan masyarakat ada sebuah stigma mengenai pentingnya pendidikan akan mempengaruhi kesungguhan pendidik dan peserta didik. Masyarakat yang masih memandang rendah pendidikan akan enggan mengirimkan anaknya ke kampus dan cenderung memandang rendah pekerjaan pengajar/tenaga pendidik. Partisipasi terhadap pendidikan juga merupakan bagian integral dari lingkungan masyarakat. Bila semua pihak telah berpartisipasi dan mendukung kegiatan pendidikan, mulai dari pemerintah (berupa kebijakan dan anggaran) sampai pada masyarakat bawah, setiap orang akan lebih menghargai dan berusaha memajukan pendidikan dan ilmu pengetahuan. Di tengah semakin ketatnya persaingan di dunia pendidikan dewasa ini, merupakan hal yang wajar apabila para mahasiswa sering khawatir akan mengalami kegagalan atau ketidak berhasilan dalam meraih prestasi belajar.

\section{KESIMPULAN DAN SARAN}

Banyak usaha yang dilakukan oleh para mahasiswa untuk meraih prestasi belajar agar menjadi yang terbaik seperti mengikuti bimbingan belajar, kelas tambahan atau bertanya langsung kepada dosen yang bersangkutan mengenai materi kuliah yang dianggap tidak mengerti. Usaha semacam itu jelas positif, namun masih ada faktor lain yang tidak kalah pentingnya dalam mencapai keberhasilan selain kecerdasan ataupun kecakapan intelektual, faktor tersebut adalah kecerdasan lingustik, logic, dan intra personal. Karena kecerdasan intelektual saja tidak memberikan persiapan bagi individu untuk menghadapi gejolak, kesempatan ataupun kesulitan-kesulitan dan kehidupan.

Dengan kecerdasan lingustik, individu mampu menggunakan kata-kata secara efektif baik secara lisan maupun tertulis. Hal ini merupakan bagian yang penting bagi mahasiswa calon guru. Karena guru adalah tempat sebagai proses transfer ilmu yang diperolehnya untuk kemudian diberikan pemahaman kepada siswa. Intinya adalah jika guru tersebut tidak memiliki kemampuan menggunakan kata-kata secara baik maka bisa diperkirakan proses transformasi ilmu juga berjalan lambat atau malah gagal.

Kecerdasan logic atau dalam istilahnya adalah kecerdasan matematika adalah kemampuan mengolah angka dan menggunakan logika atau akal sehat dengan 
baik. Masalah yang diperoleh dari penelitian ini adalah mayoritas mahasiswa masih kesulitan dalam mengembangkan pemahaman yang mereka miliki sehingga pola pikir mereka tidak dapat terbentuk dengan baik. Akibatnya mereka akan kesulitan ketika mendapatkan soal yang berbentuk analisis karena logika mereka tidak berjalan dengan baik. Padahal sebagai calon guru kecerdasan ini sangatlah diperlukan agar mengahsilkan sebuah penjelasan yang tidak hanya berdasarkan buku teks, akan tetapi diperlukan juga analisis melalui sumber-sumber lainnya yang relevan dengan materi ajar yang disampaikan.

Kecerdasan intra personal adalah sebuah kemampuan individu dalam memersepsi dan membedakan suasana hati, maksud, motivasi serta perasaan orang. Melalui kecerdasan ini individu pada umumnya dan calon guru pada khususnya akan memiliki kemampuan menanggapi perasaan mereka sendiri dengan baik dan mampu membaca dan menghadapi perasaan-perasaan orang lain. Hal ini lebih berkaitan erat dengan keterampilan emosional. Ini berarti kemungkinan besar individu tersebut akan berhasil dalam kehidupan dan memiliki motivasi untuk berprestasi. Sedangkan individu yang tidak dapat menahan kendali atas kehidupan emosionalnya akan mengalami pertarungan batin yang merusak kemampuannya untuk memusatkan perhatian pada tugas-tugasnya dan memiliki pikiran yang jernih.

Sebuah laporan dari National Center for Clinical Infant Programs (1992) menyatakan bahwa keberhasilan pendidikan seseorang bukan diramalkan oleh kumpulan fakta seorang mahasiswa atau kemampuan dirinya untuk membaca, melainkan oleh ukuranukuran emosional dan sosial yakni pada diri sendiri dan mempunyai minat, tahu pola perilaku yang diharapkan orang lain dan bagaimana mengendalikan dorongan hati untuk berbuat nakal, mampu menunggu, mengikuti petunjuk dan mengacu pada guru untuk mencari bantuan, serta mengungkapkan kebutuhan-kebutuhan saat bergaul dengan siswa lain. Hampir semua siswa yang prestasi sekolahnya buruk, menurut laporan tersebut, tidak memiliki satu atau lebih unsur-unsur kecerdasan emosional ini (tanpa memperdulikan apakah mereka juga mempunyai kesulitan-kesulitan kognitif seperti kertidakmampuan belajar). (Goleman, 2002:273).

Hal inilah yang setidaknya menjadi perhatian bagi kita para dosen pencetak guru /calon guru, agar selalu memperhatikan perkembangan kecerdasan majemuk dari masing-masing peserta didik kita agar kecerdasan majemuk tersebut bisa dan dapat berguna untuk meningkatkan kualitas keilmuan sebagai peneliti dan keprofesionalitasan sebagai guru dikemudian hari.

\section{DAFTAR RUJUKAN}

Dalyono. M. 2009. Psikologi Pendidikan. Jakarta: Rineka Cipta.

Gardner, Howard. 2003. Multiple Intelligences. Batam Centre: Interaksara. Ghozali, Imam. 2007. Aplikasi Analisis Multivariate dengan program SPSS. Semarang: Universitas Diponegoro Press.

Goleman, Daniel. 2002. Emitional Intelligence (terjemahan). Jakata : PT Gramedia Pustaka Utama.

Irwanto. 1997. Psikologi Umum. Jakarta : PT. Gramedia Pustaka Utama.

Mila Ratnawati. 1996. Hubungan antara Persepsi Anak terhadap Suasana Keluarga, Citra Diri, dan Motif Berprestasi dengan Prestasi Belajar pada Siswa Kelas V SD Ta'Miriyah Surabaya. Jurnal Anima Vol XI No. 42

Moekijat, Dasar Dasar Motivasi. Sumur Bandung, Bandung, 1984. 
Muhibbin, Syah. 2000. Psikologi Pendidikan Suharsimi, Arikunto. 2006. Prosedur dengan Suatu Pendekatan baru. Bandung : PT. Remaja Rosdakarya

Sarlito Wirawan. 1997. Psikologi Remaja. Jakarta : PT. RajaGrafindo Persada

Penelitian. Jakarta: Rineka cipta.

Sumadi, Suryabrata. 1998. Psikologi Pendidikan. Jakarta : PT. Raja Grafindo Persada

Sia, Tjundjing. 2001. Hubungan Antara IQ, Syaiful Bahri Djamarah. 2000. Prestasi EQ, dan QA dengan Prestasi Studi Pada Siswa SMU. Jurnal Anima Vol.17 no.1 Belajar Dan Kompetensi Guru. Surabaya: Usaha Nasional

Sugiyono. 2010. Metode Penelitian Winkel, WS. 1997. Psikologi Pendidikan dan Pendidikan Pendekatan Kuantitatif, Evaluasi Belajar. Jakarta : Gramedia Kualitatif dan R\&D. Bandung: Alfabeta. 